\title{
Autecological effects of habitat alteration: trophic changes in mangrove marsh fish as a consequence of marsh impoundment
}

\author{
Stanley J. Kemp* \\ Department of Biology, University of Pennsylvania, 415 S. University Avenue, Philadelphia, Pennsylvania 19104, USA \\ Present address: College of Liberal Arts, University of Baltimore, 1420 N. Charles Street, Baltimore, Maryland 21201, USA
}

\begin{abstract}
The key to predicting, counteracting, and managing environmental change is understanding the mechanisms through which habitat change affects populations of organisms. The mangrove ecosystem of the Indian River Lagoon (IRL), east-central Florida, has been impounded for the purpose of mosquito control and is representative of such large-scale alterations. Sailfin mollies Poecilia latipinna in this system exhibit significant interpopulation differences in adult body size in relation to habitat alteration. One likely hypothesis for this pattern is the apparent change in diet experienced as a result of impoundment, as has been documented in earlier studies. To address the question of whether these dietary changes would have been sufficient to cause trophic differences in $P$. latipinna populations relative to impoundment, a comparative study of trophic position in 2 sizedivergent populations of $P$. latipinna using stable isotopes was employed. Results suggested that $P$. latipinna from an unimpounded site had a slightly higher trophic position than those from an impounded site and may constitute a partial explanation of differences in adult body size between the 2 populations. Results from the present study also showed that there was a fundamental difference in energy source between the study sites, which suggests greater assimilation of mangrovebased carbon in impoundments. Specific population- and community-level effects of impoundment on mangrove habitats have been demonstrated, indicating a mechanistic link between anthropogenic habitat alteration and life history of $P$. latipinna.
\end{abstract}

KEY WORDS: Habitat alteration · Life history · Autecology · Stable isotope $\cdot$ Trophic differences · Mangrove food webs · Poecillia latipinna

Resale or republication not permitted without written consent of the publisher

\section{INTRODUCTION}

One recently developed suite of techniques which have proven to be useful in diagnosis of ecological systems (sensu Grimm et al. 1999) is the use of stable isotopes. Stable isotopes have been used to address many different types of issues in ecology, including elucidation of food webs, movements of organisms between habitats, and relative trophic structure (Peterson \& Fry 1987). One application to which stable isotopes are particularly well suited is the determination of trophic status using the relative abundance of ${ }^{15} \mathrm{~N}$ and ${ }^{13} \mathrm{C}$ in animal tissue (DeNiro \& Epstein 1981, Peterson \& Fry
1987). Isotopic ratios reflect an integration of assimilated material over a substantial time period and therefore are more representative of long-term dietary patterns than analysis of stomach contents (VanderZanden et al. 1997). Heavy isotopes of nitrogen $\left({ }^{15} \mathrm{~N}\right)$ increase predictably in tissues from organisms in higher trophic levels (Minagawa \& Wada 1984, Cabana \& Rasmussen 1996). The fraction of heavy isotopes of carbon $\left({ }^{13} \mathrm{C}\right)$ is relatively conserved between trophic levels and reflects carbon source (Fry \& Sherr, 1987, VanderZanden et al. 1999). Combined, these 2 isotopic ratios provide an effective means for comparing trophic position and the determination of the primary 
source of energy. Stable isotopes of carbon and nitrogen have been used effectively to examine both intraspecific (Gu et al. 1997) and interspecific (Beaudoin et al. 1999, Fantle et al. 1999, VanderZanden et al. 1999) differences in trophic position.

An example of an ecosystem which has been extensively altered in structure and function is the mangrove habitat found in east-central Florida. Virtually all mangrove areas along the Indian River Lagoon (IRL) were altered through impoundment, having profound impacts on the ecosystem (reviewed in Brockmeyer et al. 1997). Impoundments consist of a low head dam surrounding a mangrove marsh, by which water levels can be regulated for the purpose of controlling mosquito populations (Rey et al. 1999). One of the few studies to directly document the effects of impoundment on the mangrove ecosystem was the classic study of Harrington \& Harrington $(1961,1982)$. Part of the study observed the changes in dietary patterns of fish remaining after impoundment using gut contents. This study suggested that Poecilia latipinna populations residing in these mangrove habitats shifted trophic position as a result of impoundment (Table 1). Prior to impoundment, $30 \%$ of $P$. latipinna diet consisted of insects, mostly mosquito larvae, with the balance primarily consisting of vascular plants. Following impoundment, P. latipinna diet consisted almost entirely of algae (mostly dinoflagellates) and detritus, and the insect fraction virtually disappeared. As impoundment was highly successful at controlling mosquito populations (Brockmeyer et al. 1997), it was the likely mechanism responsible for reduction or elimination of mosquitoes from P. latipinna diets. Therefore, evidence exists that $P$. latipinna may have undergone a partial trophic shift following impoundment.

Poecilia latipinna from unimpounded sites are significantly larger than those from impounded sites (Fig. 1; Kemp 2004). Taken together, a possible hypothesis to explain this pattern was that impoundment reduced the body size of $P$. latipinna through the mechanism of reduced energy availability in the form of mosquito

Table 1. Poecilia latipinna. Proportional volume of dietary items before and after impoundment. Data are from Harrington \& Harrington (1982)

\begin{tabular}{|ll|}
\hline$\%$ by volume & Item \\
\hline Before & \\
67 & Vascular plants \\
30 & Mosquito larvae \\
2 & Other \\
1 & Phytoplankton \\
After & \\
51 & Phytoplankton \\
47 & Detritus \\
2 & Other \\
\hline
\end{tabular}

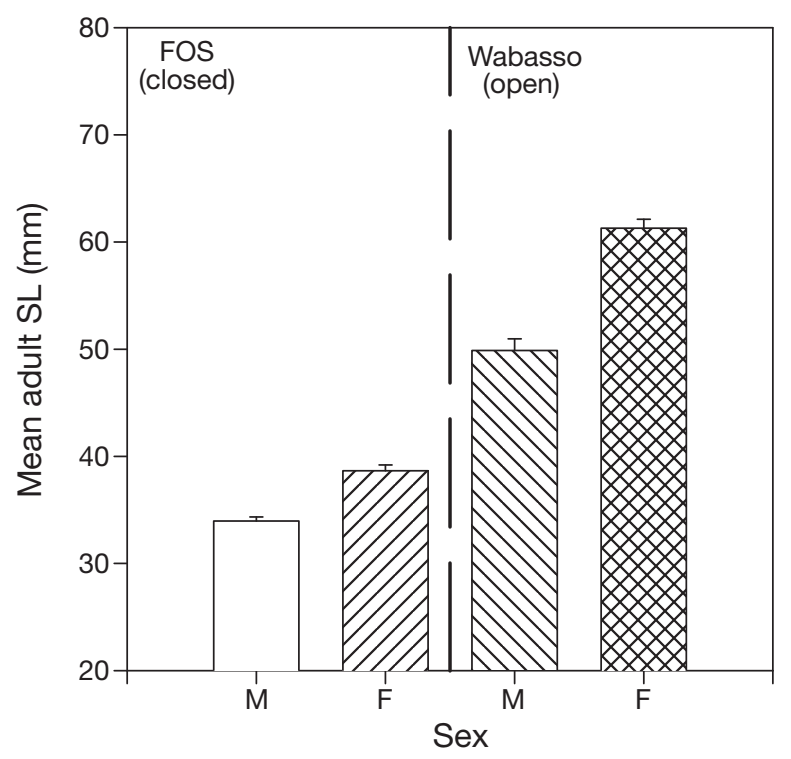

Fig. 1. Poecilia latipinna. Mean (+ 1 SE) adult standard length (SL, mm) by sex from open mangrove site (Wabasso) and closed mosquito impoundment (Florida Oceanographic Society [FOS]). Both males (M) and females (F) differ significantly between the open site and closed impoundment (males: 1-way ANOVA, df $=1,271, p<0.0001$; females: 1 -way ANOVA, df =1,147, p $<0.0001$; Kemp 2004)

larvae. The energy density of mosquito larvae is high relative to detritus or plant material, and increased net energy availability results in greater amounts of energy available for other functions such as growth (Brett \& Groves, 1979, Hewett \& Johnson, 1992, Peck \& Walton 2006). If energy allocated towards growth was greater in the open, unimpounded mangrove populations as a result of the presence of mosquito larvae, levels of ${ }^{15} \mathrm{~N}$ would be relatively higher in body tissue (DeNiro \& Epstein 1981). A comparative study of stable isotope ratios was employed to determine the difference in the contribution of plant and animal material to growth between 2 size-divergent populations and to determine if trophic shifts following impoundment may be the mechanism underlying observed patterns in body size.

\section{MATERIALS AND METHODS}

Study sites. Two study sites were chosen from an array of 8 studied mangrove marsh sites along the IRL in east-central Florida (Fig. 2). These 2 sites were selected as being representative of fully impounded and unimpounded mangrove marsh sites with sizedivergent Poecilia latipinna populations. While a more rigorous comparison could be made through the inclusion of more study sites, logistical constraints, site 


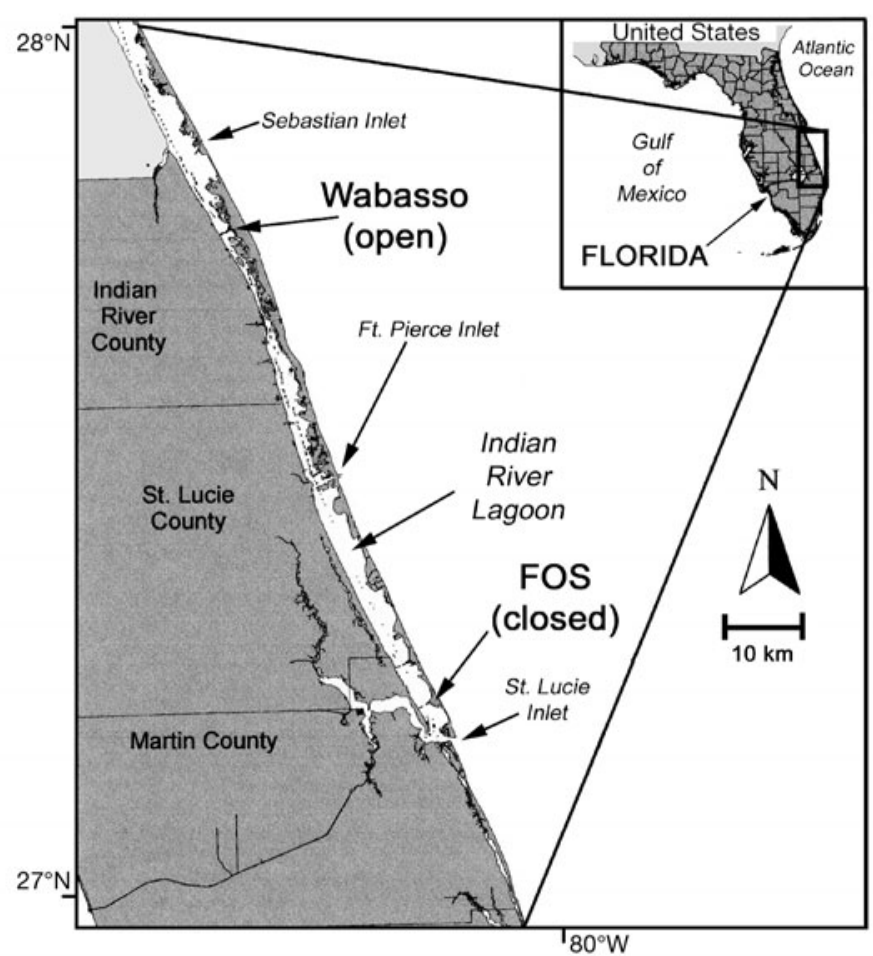

Fig. 2. Indian River Lagoon, showing locations of study sites (Florida Oceanographic Society [FOS] and Wabasso) and inlets from Atlantic Ocean

access issues, and the fact that very few unimpounded areas similar enough for comparison remain in the system precluded this possibility.

Wabasso Island (Wabasso) is located in northern Indian River County, Florida (27 $\left.45^{\prime} 50^{\prime \prime} \mathrm{N}, 80^{\circ} 26^{\prime} 70^{\prime \prime} \mathrm{W}\right)$. The site is privately owned and is currently operated as a nature preserve (Environmental Learning Center, Vero Beach, Florida). The marsh was partially ditched to facilitate tidal flushing of the island. The marsh surface is traversed by small tidal creeks running through red mangrove Rhizophora mangle, which in turn are bordered by black and white mangrove Avecinnia germinans and Laguncularia racemosa, respectively, and buttonwood Conocarpus erectus, as inundation becomes less frequent. Periodically, the entire marsh surface was inundated, and water levels fluctuated throughout the year. The marsh surface was otherwise continuous with the IRL. Adult body sizes of Poecilia latipinna were significantly higher at this site than at Florida Oceanographic Society (FOS) (Fig. 1; Wabasso adult standard length [SL] mean $[\mathrm{mm}]$ for male $=49.88 \pm 1.086 \mathrm{SE}, \mathrm{N}=25$; female $=61.30 \pm 0.828 \mathrm{SE}, \mathrm{N}=31$; Kemp 2004) .

The FOS mangrove marsh is located in Martin County along the IRL and is a semi-contained area inside a larger mosquito impoundment $\left(26^{\circ} 43^{\prime} 00^{\prime \prime} \mathrm{N}\right.$, $\left.80^{\circ} 11^{\prime} 00^{\prime \prime} \mathrm{W}\right)$, also maintained as a wildlife preserve. This area was mostly isolated from the surrounding impoundment by a series of low berms, except during times of exceptionally high water level. Therefore, only indirect, infrequent exchange occurred with waters from the IRL. Vegetation at this site consisted of well-developed red mangrove Rhizophora mangle forest. Adult body sizes of Poecilia latipinna were significantly smaller here than at Wabasso (Fig. 1; FOS adult $\mathrm{SL}$ mean $[\mathrm{mm}]$ for male $=33.96 \pm 0.391 \mathrm{SE}, \mathrm{N}=193$; female $=38.66 \pm 0.533 \mathrm{SE}, \mathrm{N}=31$; Kemp 2004).

Separated by a distance of $84 \mathrm{~km}$, both FOS (closed) and Wabasso (open) have generally very similar climates. Over the period 1948 to 2007, the average annual monthly maximum and minimum temperatures $\left({ }^{\circ} \mathrm{C}\right)$ measured at the nearest available weather recording stations (Vero Beach and Stuart) to FOS and Wabasso were 28.4 and 18.7 and 27.7 and 18.1, respectively. In addition, average annual precipitation was $147 \mathrm{~cm}$ at FOS and $130 \mathrm{~cm}$ at Wabasso. Both sites had maximum monthly average temperatures during the month of August and minimum monthly average temperatures during the month of January. Maximum monthly average precipitation for both sites was observed during September, while the minimum monthly average precipitation was observed for FOS during January and December at Wabasso (climatic data source: Center for Ocean- Atmospheric Prediction Studies at Florida State University website www. coaps.fsu.edu). Distance to the nearest inlet was $4.87 \mathrm{~km}$ for FOS and $8.78 \mathrm{~km}$ for Wabasso, and average salinities measured in the IRL at those sites were 35.4 and 31.6, respectively.

Field sampling. A representative sample of male, female, and juvenile Poecilia latipinna was collected from both study sites using cast and lift nets during July to August, 2002. It was possible to determine sex and maturity externally in the field in P. latipinna. Morphology of the male intromittent organ, the gonopodium, indicates maturity in the male, and markings near the gonopore indicate maturity in the female (Trexler \& Travis 1990). Individuals lacking these features were assumed to be juveniles. Cast nets (weighted circular nets 0.91 to $1.21 \mathrm{~m}$ radius and $63.5 \mathrm{~mm}$ bar mesh) were thrown into open areas where fish were present. Lift nets consisted of a $15.9 \mathrm{~mm}$ bar mesh net mounted in pound net style on a $1.21 \times 1.21 \mathrm{~m}$ square PVC frame. The net was hoisted from above to capture fish which collected in the center of the net. $P$. latipinna were immediately placed in water-filled specimen bags and put on ice. These samples were frozen as soon as possible for later analysis. From FOS, 10 females (33 to $46 \mathrm{~mm} \mathrm{SL}$ ), 7 males (39 to $54 \mathrm{~mm} \mathrm{SL}$ ), and 5 juveniles ( 28 to $34 \mathrm{~mm} \mathrm{SL}$ ) were used for the stable isotope analysis. From Wabasso, 17 females (40 to $68 \mathrm{~mm} \mathrm{SL}$ ), 9 males (43 to $58 \mathrm{~mm} \mathrm{SL}$ ), and 5 juveniles (33 to $42 \mathrm{~mm} \mathrm{SL}$ ) were used for the stable isotope analysis. 
For identifying site-specific differences in ambient isotopic fractions, Melampus coffeus, a detritivorous pulmonate snail, was collected for analysis. $M$ coffeus was chosen because it is the organism least likely to vary in trophic position between sites (Mook 1986), and thus reflect ambient differences in $\delta^{15} \mathrm{~N}$ isotopic ratio (Fry et al. 2000, Post 2002). Mangrove litter and detritus is a primary food source for this snail (Mook 1986), and this species is one of the main processors of mangrove detritus in this ecosystem (McKee \& Faulkner 2000, Raulerson 2004). Organisms used for this purpose should have limited dietary breadth, must be relatively long lived, and have low vagility. As M. coffeus snails feed on mangrove litter and detritus, live more than a year, and have limited scope for movement to or between sites, this species serves well as a baseline comparison organism. A series of $5 \mathrm{M}$. coffeus snails were collected from the prop roots of Rhizophora mangle at different locations from each site, immediately placed on ice, and frozen for later analysis.

Finally, representative samples of both detritus and mangrove leaves were taken at both sites. Three composite grabs of detritus and live mangrove leaves were made at separate locations at each site for stable isotope analysis. These were placed on ice for later analysis.

Sample processing. All samples were processed at the Smithsonian Marine Station in Fort Pierce, Florida. Fish samples were immediately processed following defrosting. Dissection of tissue for stable isotope analysis involved removal of skin, scales, and associated conjunctiva. Dorsal muscle tissue located above the lateral line of the fish was filleted and placed in a lyophilizer overnight to completely dehydrate the sample (freeze-dried). The isotopic ratios found in muscle tissue correspond primarily to periods of growth and mainly reflect the diet of the organism during those periods (Perga \& Gerdeaux 2005). Thus, they are most relevant to the question of how changes in Poecilia latipinna diets have affected observed adult body size differences.

Samples were temporarily stored in a dessicator and processed as soon as possible. Samples were ground using a clean, dry mortar and pestle until completely pulverized. Following the determination of the approximate carbon and nitrogen content of the samples, a sample weight was determined which would provide the analyzer with the proper amounts of each for isotopic fractionation. Samples were then weighed out to the nearest $0.1 \mathrm{mg}$ using clean dissection tools and a microbalance. These samples were then placed into previously weighed $5 \times 9 \mathrm{~mm}$ tin capsules, which were then sealed at the top and folded over into tiny cubes. These were tested for leakage before being placed into a labeled 96-well culture tray for later analysis by dropping against a dark surface.
Melampus coffeus samples were prepared by removing the shell and the gastrointestinal tract, and the remainder of the soft tissue was used in the analysis. Following dehydration using a lyophilizer, the samples were processed in an identical manner to Poecilia latipinna samples, as outlined above. Mangrove leaf and detritus samples were prepared by dehydrating a representative sample of the composite grab using the lyophilizer and then processed identically to P. latipinna samples.

Stable isotope analysis. Assay for stable isotope fractionation of carbon and nitrogen was completed at the Duke environmental stable isotope laboratory (Duke University). Fractionation was carried out using a Finnegan MAT Delta Plus XL mass spectrometer system using continuous-flow stable isotope mass spectrometry (Barrie \& Prosser 1996). Stable isotopic fractions are reported in standard delta notation, which represents a proportional difference in fraction from a given standard (atmospheric nitrogen for $\delta^{15} \mathrm{~N}$, PeeDee Belemnite for $\delta^{13} \mathrm{C}$ ). For both isotopic fractions determined, precision was ca. $\pm 0.2 \%$ at $1 \mathrm{SD}$.

Analysis of results. In order to evaluate the differences observed between populations in nitrogen fractions, values for $\delta^{15} \mathrm{~N}$ were examined in a 2-way ANCOVA for all likely sources of variation, including site and sex/stage of individual (male, female, or juvenile) as dependent variables, and SL as a covariate. It was necessary to incorporate these sources (sex and maturity), as they have been observed to impact stable isotope fractions in other studies (e.g. Genner et al. 2003). By including SL as a covariate in the model, this analysis corrected for difference in stable isotope ratios stemming from size differences alone. All factors were treated as fixed effects in the model. Data groups were tested for normality using a Shapiro-Wilk test (Sall \& Lehman 1996). Homogeneity of slopes (Sokal \& Rohlf 1981) was determined by implementing a full factorial, 3-way ANOVA with sex, site, and SL as factors. The lack of significant interactions between SL and other factors affirmed homogeneity of slopes. A post hoc test to determine differences between sex/stage groups within sites was carried out using a $\mathrm{T}^{\prime}$ test (Sokal \& Rohlf 1981).

A similar 2-way ANCOVA analysis was used to evaluate intersite differences in $\delta^{13} \mathrm{C}$, also including site and sex/stage of individuals (male, female, or juvenile) as dependent variables, and SL as a covariate. All factors were treated as fixed effects. Prior to running the analysis, homogeneity of slopes was tested in an identical manner to that described above for ratios and was confirmed. Differences between sex/stage groups within sites were analyzed using a post hoc $\mathrm{T}^{\prime}$ test as for $\delta^{15} \mathrm{~N}$ values. 


\section{RESULTS}

\section{Stable isotope fractions of Poecilia latipinna}

Stable isotope fractions of both carbon and nitrogen are shown in Table 2. In the ANCOVA, differences attributable to site were significant, with $\delta^{15} \mathrm{~N}$ values at Wabasso (open) significantly greater than those from FOS (closed) ( $p<0.05$, Table 3$)$. The difference in mean $\delta^{15} \mathrm{~N}$ values between sites was equal to $0.52 \%$. Sex was a highly significant factor $(p<0.0001)$ in the model, while the sex by site interaction term was not significant. At both sites, mean $\delta^{15} \mathrm{~N}$ levels were highest in males, intermediate for females, and lowest in juveniles. The post hoc $\mathrm{T}^{\prime}$ test comparing sex/stage groups between sites showed similar patterns at both sites. At both sites, male and female $\delta^{15} \mathrm{~N}$ levels were significantly greater than juveniles, but were not significantly different from each other.

Table 2. Poecilia latipinna, Melampus coffeus, mangrove leaf and detritus. Mean $\pm \mathrm{SE}$ of stable isotope fractions of carbon and nitrogen for items collected at Florida Oceanographic Society (FOS) (closed impoundment) and Wabasso (open). Values in bold indicate those that are significantly different $(\mathrm{p}<0.05)$ from their counterpart measurements at the other site ( $P$. latipinna: 2-way ANCOVA, $M$. coffeus, mangrove leaf, detritus: 1-way ANOVA). $\mathrm{N}$ indicates sample size

\begin{tabular}{|lccc|}
\hline Source & $\mathrm{N}$ & $\delta^{15} \mathrm{~N}(\%)$ & $\delta^{13} \mathrm{C}(\%)$ \\
\hline P. latipinna & & & \\
Wabasso (open) & 31 & $\mathbf{6 . 2 2} \pm \mathbf{0 . 1 2 1}$ & $\mathbf{- 2 6 . 2 2} \pm \mathbf{0 . 1 5 5}$ \\
FOS (closed) & 21 & $\mathbf{5 . 7 0} \pm \mathbf{0 . 1 8 8}$ & $\mathbf{- 2 9 . 7 0} \pm \mathbf{0 . 3 4 3}$ \\
$\mathbf{M}$ coffeus & & & \\
Wabasso (open) & 5 & $2.58 \pm 0.043$ & $\mathbf{- 2 5 . 9 2} \pm \mathbf{0 . 2 2 4}$ \\
FOS (closed) & 5 & $2.43 \pm 0.106$ & $\mathbf{- 2 7 . 5 0} \pm \mathbf{0 . 4 8 7}$ \\
Mangrove leaf & & & \\
Wabasso (open) & 3 & $2.28 \pm 0.838$ & $\mathbf{- 2 7 . 1 4} \pm \mathbf{0 . 4 3 3}$ \\
FOS (closed) & 3 & $0.85 \pm 0.802$ & $\mathbf{- 3 0 . 1 9} \pm \mathbf{0 . 6 1 3}$ \\
$\begin{array}{l}\text { Detritus } \\
\text { Wabasso (open) }\end{array}$ & 3 & $1.56 \pm 0.345$ & $-28.38 \pm 0.389$ \\
FOS (closed) & 3 & $1.00 \pm 0.189$ & $-29.28 \pm 0.243$ \\
\hline
\end{tabular}

Table 3. ANCOVA for Poecilia latipinna. $\delta^{15} \mathrm{~N}$ vs. site and sex with standard length (SL) as a covariate. All model effects were treated as fixed. Probabilities in bold are significant $(\mathrm{p}<0.05)$

\begin{tabular}{|lrrcc|}
\hline Source & df & SS & $F$ Ratio & Prob $>F$ \\
\hline Sex & 2 & 7.34 & 9.03 & $\mathbf{0 . 0 0 0 5}$ \\
Site & 1 & 2.04 & 5.02 & $\mathbf{0 . 0 3 0 2}$ \\
Site $\times$ Sex & 2 & 0.27 & 0.33 & 0.7181 \\
SL & 1 & 0.00 & 0.00 & 0.9468 \\
Error & 44 & 17.88 & & \\
\hline
\end{tabular}

In the ANCOVA performed for $\delta^{13} \mathrm{C}$ differences, site was a highly significant $(\mathrm{p}<0.0001)$ factor in the model, but neither sex nor the sex by site interaction was significant (Table 4). The $\delta^{13} \mathrm{C}$ values from Wabasso (open) $P$. latipinna were significantly greater $(\mathrm{p}<$ 0.0001) than those for P. latipinna from FOS (closed), and the average difference in $\delta^{13} \mathrm{C}$ between populations was equal to $3.48 \%$. The post hoc $\mathrm{T}^{\prime}$ test comparing sex/stage groups within sites for $\delta^{13} \mathrm{C}$ differences showed no significant differences between these groups within sites, although all groups from Wabasso (open) were significantly greater $(\mathrm{p}<0.05)$ than those from FOS (closed).

\section{Stable isotope fractions of Melampus coffeus}

A 1-way ANOVA was used to evaluate intersite differences in carbon and nitrogen stable isotope fractions found in populations of the baseline organism Melampus coffeus. Values of $\delta^{15} \mathrm{~N}$ were similar at both sites, though there was greater variation present in samples from FOS (Table 2). Comparison of $\delta^{15} \mathrm{~N}$ values using a 1-way ANOVA with site as fixed effect revealed no significant difference in terms of $\delta^{15} \mathrm{~N}$ between $M$. coffeus from FOS and Wabasso ( $\mathrm{df}=1,9$; $\mathrm{SS}=0.05 ; \mathrm{p}=0.2365)$. However, an identical 1-way ANOVA with $\delta^{13} \mathrm{C}$ ratios as the response showed that $M$. coffeus from Wabasso had significantly greater $\delta^{13} \mathrm{C}$ values over those from FOS $(\mathrm{df}=1,9 ; \mathrm{SS}=6.21 ; \mathrm{p}=$ 0.0188). The mean difference between sites in $\delta^{13} \mathrm{C}$ was on average equal to $1.58 \%$, under half of the average difference between FOS and Wabasso Poecilia latipinna.

\section{Mangrove and detritus samples}

Stable isotope fractions of both carbon and nitrogen measured for mangrove leaf and detritus samples are shown in Table 2. A 1-way ANOVA with site as a fixed effect showed no significant difference between sites

Table 4. ANCOVA for Poecilia latipinna. $\delta^{13} \mathrm{C}$ vs. site and sex with standard length (SL) as a covariate. All effects in model were treated as fixed. Probability in bold is significant $(\mathrm{p}<0.05)$

\begin{tabular}{|lrrrr|}
\hline Source & df & \multicolumn{1}{c}{ SS } & FRatio & Prob $>F$ \\
\hline Sex & 2 & 4.42 & 1.74 & 0.1879 \\
Site & 1 & 85.35 & 67.12 & $<\mathbf{0 . 0 0 0 1}$ \\
Site $\times$ Sex & 2 & 4.08 & 1.60 & 0.2125 \\
SL & 1 & 0.70 & 0.55 & 0.4629 \\
Error & 44 & 55.95 & & \\
\hline
\end{tabular}


in mangrove leaf $\delta^{15} \mathrm{~N}(\mathrm{df}=1,5 ; \mathrm{SS}=3.11 ; \mathrm{p}=0.2824)$, and a 1-way ANOVA with site as a fixed effect showed the difference in $\delta^{13} \mathrm{C}$ between sites to be significant (df = 1,5; SS = 13.99; $\mathrm{p}=0.0152$ ).

For detritus samples, a 1-way ANOVA with site as a fixed effect showed that the difference in $\delta^{15} \mathrm{~N}$ between sites was not significant ( $\mathrm{df}=1,5 ; \mathrm{SS}=0.40 ; \mathrm{p}=$ 0.2603 ), and a 1-way ANOVA with site as a fixed effect showed that the difference in $\delta^{13} \mathrm{C}$ between sites was also not significant ( $\mathrm{df}=1,5 ; \mathrm{SS}=1.23 ; \mathrm{p}=0.1200$ ).

In summary, no significant difference was observed between $\delta^{15} \mathrm{~N}$ values for detritus or mangrove leaf samples collected at Wabasso and FOS. For $\delta^{13} \mathrm{C}$, only the differences in mangrove leaf means were significant $(\mathrm{p}<$ 0.05), which were elevated at the open site (Wabasso).

\section{Poecilia latipinna individual samples}

Individual Poecilia latipinna values for $\delta^{15} \mathrm{~N}$ and $\delta^{13} \mathrm{C}$ are plotted in Fig. 3. Most P. latipinna from Wabasso, except for 2 juveniles, are loosely clustered along $\delta^{15} \mathrm{~N}$ and $\delta^{13} \mathrm{C}$ axes. Individuals from FOS show more variation in these parameters, especially among males. A single individual male from FOS appears to fall in the range of extreme values for Wabasso. Average values for $\delta^{15} \mathrm{~N}$ for fish from FOS would have been less had it not been for the variation observed within FOS males.

\section{Comparison of Melampus coffeus and Poecilia latipinna}

A visualization of the overall $\delta^{15} \mathrm{~N}$ and $\delta^{13} \mathrm{C}$ values for both Poecilia latipinna and Melampus coffeus at

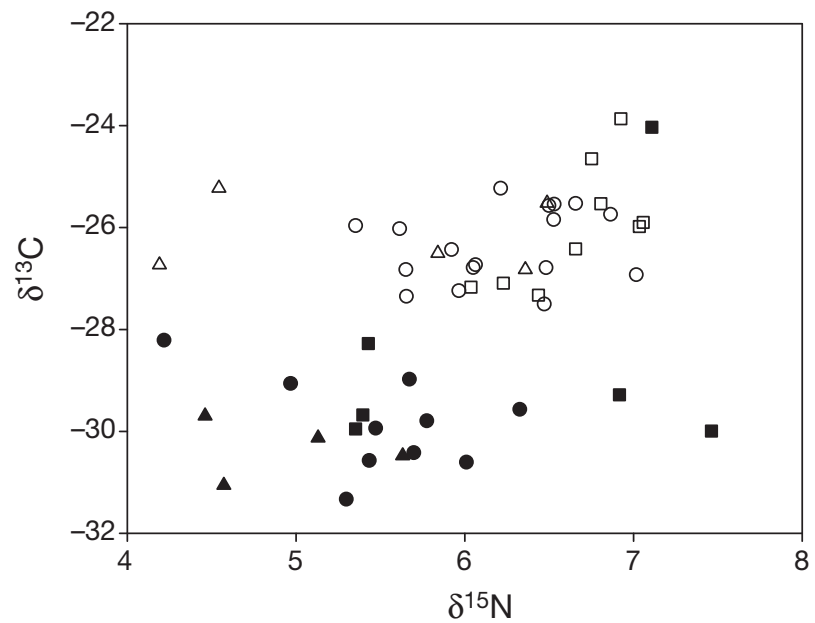

Fig. 3. Poecilia latipinna. Scatterplot of measured $\delta^{13} \mathrm{C}(\%)$ vs. $\delta^{15} \mathrm{~N}(\%)$ coded by site (white markers = Wabasso [open], black markers $=$ FOS [closed]) and sex/stage (circles = females, squares = males, and triangles $=$ juveniles)

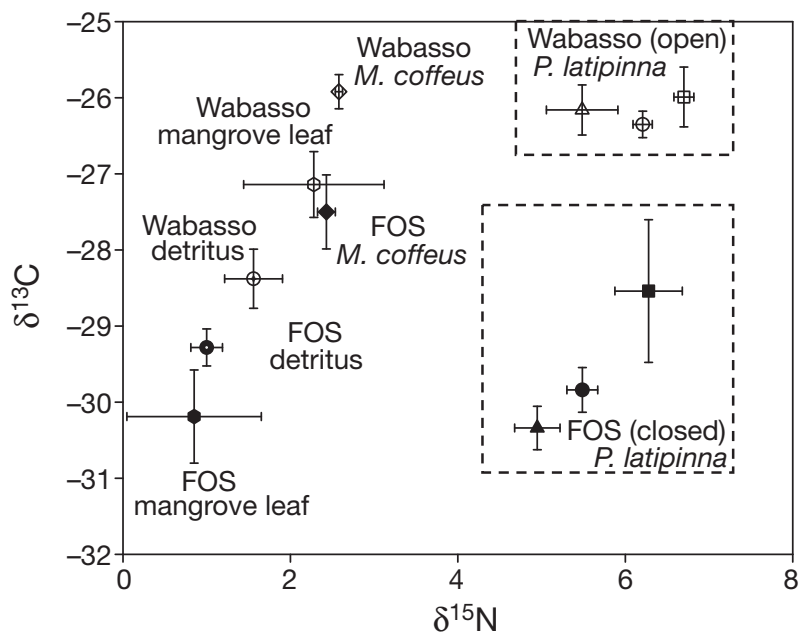

Fig. 4. Scatterplot of mean ( $\pm 1 \mathrm{SE}) \delta^{13} \mathrm{C}(\%)$ and $\delta^{15} \mathrm{~N}(\%)$ of Poecilia latipinna grouped by sex and site, Melampus coffeus grouped by site, and mangrove leaves and detritus grouped by site. White symbols represent samples collected at Wabasso (open) and black symbols represent those collected at Florida Oceanographic Society (FOS) (closed). For P. latipinna, triangles denote juveniles, circles denote females, and squares denote males

each site is presented in Fig. 4. While M. coffeus are strongly differentiated between sites along the $\delta^{13} \mathrm{C}$ axis, they are in similar, statistically identical positions along the $\delta^{15} \mathrm{~N}$ axis. $P$. latipinna from each site are also differentiated along the $\delta^{13} \mathrm{C}$ axis in a similar manner to $M$. coffeus, although to a greater degree. The $\delta^{15} \mathrm{~N}$ values for $P$. latipinna from Wabasso (open) are shifted slightly higher than those from FOS (closed). Values of $\delta^{15} \mathrm{~N}$ for $P$. latipinna were at both sites much higher than those from $M$. coffeus. In summary, both $M$. coffeus and $P$. latipinna had intersite differences in $\delta^{13} \mathrm{C}$, although the differences between $M$. coffeus were about half the difference observed for P. latipinna. The values for $\delta^{13} \mathrm{C}$ were depleted for $P$. latipinna relative to $M$. coffeus (Fig. 4) at both sites.

\section{DISCUSSION}

\section{Intersite stable isotope baseline comparison}

The pulmonate snail Melampus coffeus provided a readily available organism to investigate baseline differences in carbon and nitrogen stable isotope ratios. Results indicated that $\delta^{15} \mathrm{~N}$ in $M$. coffeus at both sites was statistically identical, and there was a consistent difference in $\delta^{13} \mathrm{C}$ between populations. Because these organisms are not likely to vary extensively in diet, are relatively long-lived, and are consumers, they most likely would reflect relative differences in ambient $\delta^{15} \mathrm{~N}$ between the 2 sites (Post 2002). One interesting 
aspect of the results is that while both Poecilia latipinna and $M$. coffeus are mostly first-order consumers, the overall values for $\delta^{15} \mathrm{~N}$ are much lower for $M$. coffeus. In addition, the difference between $M$. coffeus populations in $\delta^{13} \mathrm{C}$ was much lower than the difference observed between $P$. latipinna populations. In a metanalysis, Vanderklift \& Posnard (2003) found that some invertebrates, particularly gastropods, appear to fractionate stable isotopes less than vertebrates. Alternatively, the results may also be explained, partially or fully, by the dietary and trophic differences between the 2 species. In any case, results indicate that there is no difference in baseline $\delta^{15} \mathrm{~N}$ between sites, and that there is a significant difference in baseline $\delta^{13} \mathrm{C}$ between sites. This result is crucial to the interpretation of the stable isotope ratios from the 2 populations, as any relative intersite differences can be assumed to reflect intersite differences in diet.

\section{Interpopulation differences in $\delta^{15} \mathbf{N}$ for Poecilia latipinna}

In summary, results show significant differences in $\delta^{15} \mathrm{~N}$ for Poecilia latipinna from the open (Wabasso) and closed impoundment (FOS) populations, although the interpopulation difference in $\delta^{13} \mathrm{C}$ is much larger than that measured for $\delta^{15} \mathrm{~N}$ (Fig. 4). These results also revealed significant ontogenetic differences in these ratios within populations.

The main focus of the present study was to evaluate the hypothesis that observed patterns in body size and life history in Poecilia latipinna populations are due to reduced availability of animal protein (primarily mosquito larvae) as a result of impoundment. This evaluation depended strongly on the outcome of the intersite differences in $\delta^{15} \mathrm{~N}$ values. Given the equivalent baseline established by the Melampus coffeus samples, the expectation would be an enrichment of $\delta^{15} \mathrm{~N}$ in tissues from $P$. latipinna at the open site (Wabasso) if the hypothesis were valid and mosquito larvae had contributed to growth disproportionately. While there has been broad agreement in the literature regarding the correlation between trophic position and enrichment of $\delta^{15} \mathrm{~N}$, the degree of enrichment may not be constant across taxa. Also, other factors, such as mode of nitrogen excretion and nutritional status, may also affect it (Vanderklift \& Posnard 2003). The mean difference in $\delta^{15} \mathrm{~N}$ between populations was ca. $0.52 \%$, a fraction of the difference expected for separation of an entire trophic level (2.96\%; Vanderklift \& Posnard 2003).

The interpopulation difference in $\delta^{15} \mathrm{~N}$ suggests that the relative contribution from animal protein sources (such as mosquito larvae) to growth in Poecilia latipinna at the open mangrove site (Wabasso) is slightly higher than that found in the mosquito impoundment (FOS). Perga \& Gerdeaux (2005) found that muscle tissue has a relatively low level of annual variation in stable isotope ratios and that these ratios reflect the diets experienced during growth periods. In the mangrove ecosystem, the main growth periods of $P$. latipinna and the breeding period of the saltmarsh mosquito coincide and occur between the months of April and October (Snelson 1984, Smith 1988, Rey et al. 1999). Therefore, growth in these populations can be attributed primarily to diets experienced during this time, and any assimilated proteins originating from mosquito larvae as a food source would be reflected in the isotopic signature of those tissues. Any enrichment in $\delta^{15} \mathrm{~N}$ can most likely be attributed to mosquito larvae, as large broods emerge in the habitat periodically throughout this season (Brockmeyer et al. 1997). While other sources of nitrogen exist for an opportunist such as $P$. latipinna, several facts highlight the probable importance of mosquito larvae. P. latipinna are opportunistic predators at best and are often described as being completely herbivorous (e.g. Robins \& Ray 1986). Also, the measured nitrogen content of mosquito larvae is high (10 to $12.4 \%$; Peck \& Walton 2006), relative to other potential energy sources of $P$. latipinna, such as mangrove detritus $(<3 \%$ in Rhizophora detritus; Woitchik et al. 1997, Lugendo et al. 2006, present study). The data indicate a significant enrichment in $\delta^{15} \mathrm{~N}$ in the muscle tissue of $P$. latipinna from the open (Wabasso) site relative to those at the closed impoundment (FOS). This suggests that the relative contribution of animal protein sources at the open site during times of growth is somewhat higher than in mosquito impoundments. While not on the scale of the difference expected for an entire trophic level, the interpopulation differences measured in $\delta^{15} \mathrm{~N}$ may be important relative to the comparative life history of these populations.

The significant difference between populations in $\delta^{15} \mathrm{~N}$ is in the predicted direction of an increased intake of animal material at the open mangrove site, as suggested by Harrington \& Harrington $(1961,1982)$. Mosquito broods in natural mangrove marsh proliferate unpredictably during the mosquito mating season, and therefore mosquito larvae comprise an irregularly timed, pulse food source for Poecilia latipinna populations. The fact that these pulses come during the main part of the growing season suggests that pulse inputs of mosquito larvae may be a partial contributing factor to observed interpopulation body size differences. Strong selective forces exist for both rapid growth and attainment of maturity prior to the onset of winter. Overwintering mortality is extensive in P. latipinna populations (Snelson 1984, Trexler et al. 1992), and survival until the next favorable reproductive period is uncertain. 
Since growth in $P$. latipinna is strongly curtailed or halted following maturation (Snelson 1984), adult body size effectively approximates size at maturity. An ecological tradeoff is known to exist between larger body size and time to maturation. Larger males achieve more mating success (Ptacek \& Travis 1997), and larger females produce more eggs. However, the longer it takes to achieve size at maturation, the greater the risk of predation, and therefore, a selective balance exists between survival and reproductive factors. Adult body sizes in $P$. latipinna have a large documented genetic component, with potentiality for size at maturity in males being determined by a Y-linked allele (Travis 1994). Subdivision of the mangrove system through impoundment reduced the connectivity between $P$. latipinna populations and may have also enhanced sitespecific selection. Taken together, it is clear that any advantage conferred in terms of energy available during the growth season may have led to the greater body sizes seen in the open population by altering the selective balance of the ecological tradeoff in body size.

An unpredicted, consistent significant difference within populations in terms of $\delta^{15} \mathrm{~N}$ was observed between adults and juveniles (Fig. 4). Adults were consistently enriched in $\delta^{15} \mathrm{~N}$ relative to juveniles, and males were consistently enriched relative to females, though the latter difference was not significant at either site. Differences in $\delta^{15} \mathrm{~N}$ in the same direction relative to ontogeny were observed by Bouillon et al. (2002a), along with significant intersexual differences. One possible reason for these ontogenetic shifts may be related to the increase in gape size of adults relative to juveniles. This would allow for the consumption of larger prey items of increasingly higher trophic level (Cocheret de la Morinière et al. 2003). One hypothesis which can be immediately ruled out is the direct correlation of $\delta^{15} \mathrm{~N}$ with size, which has been observed in some populations (Genner et al. 2003). Within these and other Poecilia latipinna populations studied (Kemp 2004), females were universally larger than males. However, in the present study, females were intermediate in $\delta^{15} \mathrm{~N}$ between juveniles and males. One speculation regarding this difference may be differing physiological or allocational needs of male and female $P$. latipinna. It has been demonstrated in this system that within $P$. latipinna populations, non-reproductive females have greater length-specific mass than males (Kemp 2004), thus suggesting the possibility that males differ from females in allocation patterns.

\section{Poecilia latipinna interpopulation differences in $\delta^{13} \mathrm{C}$}

An auxiliary result to the main focus of the present study was the measurement of significant interpopula- tion differences in $\delta^{13} \mathrm{C}$. Because isotopic signatures of all food sources for $\delta^{13} \mathrm{C}$ were not determined, these results could not be used to specifically identify food sources. However, there was a significant enrichment in both Poecilia latipinna and Melampus coffeus in $\delta^{13} \mathrm{C}$ from the open mangrove site (Wabasso) versus the closed site (FOS). This may be an indication of an overall difference in carbon source between the 2 sites. Little enrichment occurs in $\delta^{13} \mathrm{C}$ relative to trophic position, and most variation is set at the level of primary producer (DeNiro \& Epstein 1978). Several other studies have shown that as distance to marine-influenced habitats (such as the IRL) increased, similar depletions in $\delta^{13} \mathrm{C}$ were observed (Bouillon et al. 2002a, Lugendo et al. 2006). Carbon sources found in open marine systems have been found to be enriched in $\delta^{13} \mathrm{C}$ (Fry \& Sherr 1987). Pineda (2003) found that assimilation of mangrove-based carbon by organisms increased as marine influence decreased. One possible reason for this pattern is that carbon exports from other ecosystems such as seagrass may increase along with interconnectivity (Bouillon et al. 2002b, Connolly et al. 2005). Relevant to the present study, the restriction of the exchange of carbon and other materials caused by impoundment may have resulted in an increased amount of mangrove-based carbon assimilated at FOS, reflected in its isotopic signature. This suggestion is further supported by the fact that $\delta^{13} \mathrm{C}$ signatures found in the $P$. latipinna from FOS match the relatively depleted $\delta^{13} \mathrm{C}$ values of the mangrove leaves and detritus found there fairly closely, opposite of that found at Wabasso. Therefore, an influx of carbon sources from surrounding habitats at Wabasso appears to be a viable hypothesis to explain the consistent intersite difference in $\delta^{13} \mathrm{C}$. In summary, the separation of the mangrove habitats from the IRL caused by impoundment may have altered mangrove food webs by increasing the importance of mangrove-based carbon sources.

\section{CONCLUSIONS}

The results of the present study have shed light on the population-level effects of impoundment of a mangrove marsh in the IRL ecosystem. Large-scale anthropogenic impacts typically have both direct and indirect effects on the ecosystem. Mosquito impoundments are no exception to this general rule. The construction of low head dams around mangrove habitat restricted tidal flushing of the area from the adjacent lagoon and movement of biota in and out of mangrove areas (Gilmore et al. 1982, Brockmeyer et al. 1997, Rey et al. 1999). The number of potential effects of impoundment on any particular population is very great, and the key to attaining understanding of an 
observed effect is to isolate the primary mechanisms impacting the life history of the population (Dunham 1993). The mechanistic hypothesis proposed underlying the observed life history differences in this case made specific predictions, which were tested using stable isotope techniques. The results from the present study suggest a partial role for the effects of human habitat change (impoundment) on diet in producing observed life-history patterns in this system. The larger adult body sizes in populations from the open site (Wabasso) may have been contributed to by an increased amount of animal protein available during the growing season, as suggested by the seminal studies of Harrington \& Harrington (1961, 1982). One intriguing result emerging from the present study highlights the effects that impoundment may have had on mangrove food webs. Other potential mechanisms underlying population-level effects which remain to be explored in this habitat include differential overwintering survivorship, aspects of predation pressure, and effects of resource limitation. Ultimately, the explanation for the observed interpopualtion life-history differences may be multifactorial. Recognition of the importance of mangrove habitats in the IRL has led to an extensive effort in its restoration (Rey et al. 1999). While restoration efforts of mangrove ecosystems have been successful in many ways, often little attention is paid to the detailed population- and community-level information available for the ecosystem, if it exists at all (Ellison 2000). Identification of the specific effects of habitat alteration, as presented here, is an essential link between ecological science and restoration efforts in mangrove habitats.

Acknowledgements. This research was conducted through the support of a Link Fellowship at Smithsonian Marine Station (SMS), Fort Pierce, FL. The following individuals were helpful: I. Feller, M. Rice, J. Piraino, W. Lee, and other SMS staff; A. Dunham, P. Petraitis, B. Casper (University of Pennsylvania); M. O'Connor (Drexel University); J. McNair (Academy of Natural Sciences); J. Rey (FMEL); J. Karr (Duke Environmental Stable Isotope Laboratory). Also, thanks are due to Harbor Branch Library, Florida Oceanographic Society (Stuart, FL), and Environmental Learning Center (Wabasso, FL). This is contribution number 754 from the Smithsonian Marine Station.

\section{LITERATURE CITED}

Barrie A, Prosser SJ (1996) Automated analysis of lightelement stable isotopes by isotope ratio spectrometry. In: Boutton TW, Yamasaki, SI (eds) Mass spectrometry of soils. Marcel Dekker, New York, p 1-46

Beaudoin CP, Tonn WT, Prepas EE, Wassenaar LI (1999) Individual specialization and trophic adaptability of northern pike (Esox lucius): an isotope and dietary analysis. Oecologia 120:386-396

Bouillon S, Raman AV, Dauby P, Dehairs F (2002a) Carbon and nitrogen stable isotope ratios of subtidal benthic invertebrates in an estuarine mangrove ecosystem (Andhra Pradesh, India). Estuar Coast Shelf Sci 54:901-913

Bouillon S, Koedam N, Raman AV, Dehairs F (2002b) Primary producers sustaining macro-invertebrate communities in intertidal mangrove forests. Oecologia 130:441-448

Brett JR, Groves T (1979) Physiological energetics. In: Hoar WS, Randall DJ, Brett JR (eds) Fish physiology, Vol III. Academic Press, New York, p 279-352

Brockmeyer RE, Rey JR, Virnstein RW, Gilmore RG, Earnest L (1997) Rehabilitation of impounded estuarine wetlands by hydrologic reconnection to the Indian River Lagoon, Florida. J Wetlands Ecol Manag 4:93-109

Cabana G, Rasmussen JB (1996) Comparison of aquatic food chains using nitrogen isotopes. Proc Natl Acad Sci USA 93:10844-10847

> Cocheret de la Morinière E, Pollux BJA, Nagelkerken I, Hemminga MA, Huiskes AHL, van der Velde G (2003) Ontongenetic dietary changes of coral reef fishes in the mangrove-seagrass-reef continuum: stable isotopes and gut-content analysis. Mar Ecol Prog Ser 246:279-289

Connolly RM, Gorman D, Guest MA (2005) Movement of carbon among estuarine habitats and its assimilation by invertebrates. Oecologia 144:684-691

DeNiro MJ, Epstein S (1978) Influence of diet on the distribution of carbon isotopes in animals. Geochim Cosmochim Acta 42:495-506

> DeNiro MJ, Epstein S (1981) Influence of diet on the distribution of nitrogen isotopes in animals. Geochim Cosmochim Acta 45:341-351

Dunham AE (1993) Population responses to environmental change: operative environments, physiologically structured models, and population dynamics. In: Karieva $\mathrm{P}$, Kingsolver J, Huey RB (eds) Biotic interactions and global change. Sinauer Associates, Sunderland, MA, p 95-119

Ellison AM (2000) Mangrove restoration: Do we know enough? Restor Ecol 8:219-229

Fantle MS, Dittle AI, Schwalm SM, Epifiano CE, Fogel ML (1999) A food web analysis of the juvenile blue crab, Callinectes sapidus, using stable isotopes in whole animals and individual amino acids. Oecologia 120:416-426

Fry B, Sherr EB (1987) $\delta^{13} \mathrm{C}$ measurements as indicators of carbon flows in marine and freshwater ecosystems. Contrib Mar Sci 27:13?47

Fry B, Bern AL, Ross MS, Meeder JF (2000) $\delta^{15} \mathrm{~N}$ studies of nitrogen use by the red mangrove, Rhizophora mangle L. in South Florida. Estuar Coast Shelf Sci 50:291-296

Genner MJ, Hawkins SJ, Turner GF (2003) Isotopic change throughout the life history of a Lake Malawi cichlid fish. J Fish Biol 62:907-917

Gilmore RG, Cooke DW, Donohoe CJ (1982) A comparison of the fish populations and habitat in open and closed salt marsh impoundments in east-central Florida. Northeast Gulf Sci 5:25-37

> Grimm V, Wyszomiriski T, Ackman D, Uchmanski J (1999) Individual-based modeling and ecological theory: synthesis of a workshop. Ecol Modell 115:275-282

Gu B, Schelske CL, Hover MV (1997) Intrapopulation feeding diversity in blue tilapia: evidence from stable-isotope analysis. Ecology 78:2263-2266

- Harrington RW, Harrington ES (1961) Food selection among fishes invading a high subtropical marsh: from onset of flooding through the progress of a mosquito brood. Ecology 42:646-666

Harrington RW, Harrington ES (1982) Effects on fishes and their forage organisms of impounding a Florida salt marsh to prevent breeding by salt marsh mosquitoes. Bull Mar Sci 32:523-531 
Hewett SW, Johnson BL (1992) A generalized bioenergetics model of fish growth for microcomputers (model 2). University of Wisconsin, Sea Grant Technical Reports WSSG- 92- 250, Madison, WI

Kemp SJ (2004) Ecology of life history variation in the sailfin molly (Poecilia latipinna) in impounded mangrove marsh of the Indian River Lagoon, Florida. PhD dissertation. University of Pennsylvania, PA

Lugendo BR, Nagelkerken I, van der Velde G, Mgaya YD (2006) The importance of mangroves, mud and sand flats, and seagrass beds as feeding areas for juvenile fishes in Chwaka Bay, Zanzibar: gut content and stable isotope analyses. J Fish Biol 69:1639-1661

McKee KL, Faulkner PL (2000) Restoration of biogeochemical function in mangrove forests. Restor Ecol 8:247-259

Minagawa M, Wada E (1984) Stepwise enrichment of ${ }^{15} \mathrm{~N}$ along food chains: further evidence and the relation between $\delta^{15} \mathrm{~N}$ and algae. Geochim Cosmochim Acta 48:1135-1140

Mook, D (1986) Absorption efficiencies of the intertidal mangrove dwelling mollusk Melampus coffeus and the rocky intertidal mollusk Acanthopleura granulata Gmelin. PSZN I: Mar Ecol 7:105-113

Peck GW, Walton WE (2006) Effect of bacterial quality and density on growth and whole body stoichiometry of Culex quinquefasciatus and Culex tarsalis (Diptera: Culicidae). J Med Entomol 43:25-33

Perga ME, Gerdeaux D (2005) 'Are fish what they eat' all year round? Oecologia 144:598-606

Peterson BJ, Fry B (1987) Stable isotopes in ecosystem studies. Annu Rev Ecol Syst 18:293-320

Pineda JEM (2003) The contribution of mangrove outwelling to coastal food webs as a function of environmental settings. PhD dissertation, University of Louisiana, Lafayette, LA

Post DM (2002) Using stable isotopes to estimate trophic position: models, methods and assumptions. Ecology 83: 703-718

Ptacek MB, Travis J (1997) Mate choice in the sailfin molly, Poecilia latipinna. Evolution 51:1217-1231

Raulerson GE (2004) Leaf litter processing by macrodetritivores in natural and restored neotropical mangrove forests. PhD dissertation, Louisiana State University and Agricultural and Mechanical College, Baton Rouge, LA

Initial editorial responsibility: Howard Browman, Storebø, Norway; Final editorial responsibility: Matthias Seaman, Oldendorf/Luhe, Germany
Rey JP, Carlson DB, Carroll JD (1999) Regional marsh strategies for the Indian River Lagoon. Tech Bull Fla Mosq Control Assoc 2: A1-G15

Robins CR, Ray GC (1986) A field guide to Atlantic coast fishes of North America. Houghton Mifflin, Boston, MA

Sall J, Lehman A (1996) JMP start statistics: a guide to statistics and data analysis using JMP and JMP IN software. Duxbury Press, New York

Smith RB (1988) Variation in female somatic condition and its relationship to reproduction in the sailfin molly, Poecilia latipinna (Pisces: Poeciliidae). MSc thesis, University of Central Florida, Orlando, FL

$>$ Snelson FF (1984) Seasonal maturation and growth of males in a natural population of Poecilia latipinna. Copeia 1984: $252-255$

Sokal RR, Rohlf FJ (1981) Biometry, 2nd edn. WH Freeman, New York

Travis J (1994) Evolution in the sailfin molly: the interplay of life-history variation and sexual selection. In: Real LA (ed) Ecological genetics, Princeton University Press, Princeton, NJ, p 205-232

Trexler JC, Travis J (1990) Phenotypic plasticity in the sailfin molly, Poecilia latipinna (Pisces: Poecillidae). I. field experiments. Evolution 44:144-156

Trexler JC, Travis J, McManus M (1992) Effects of habitat and body size on mortality rates of Poecilia latipinna. Ecology 73:2224-2236

Vanderklift MA, Posnard S (2003) Sources of variation in consumer-diet $\delta^{15} \mathrm{~N}$ enrichment: a meta-analysis. Oecologia 136:169-182

VanderZanden MJ, Cabana G, Rasmussen JB (1997) Comparing trophic position of freshwater fish calculated using stable isotope ratios $\left(\delta^{15} \mathrm{~N}\right)$ and literature dietary data. Can J Fish Aquat Sci 54:1152-1158

VanderZanden MJ, Casselman JM, Rasmussen JB (1999) Stable isotope evidence for the food web consequences of species invasions in lakes. Nature 401:464-467

- Woitchik AF, Ohowa B, Kazungu JM, Rao RG, Goyens L, Dehairs F (1997) Nitrogen enrichment during decomposition of mangrove leaf litter in an East African coastal lagoon (Kenya): relative importance of biological nitrogen fixation. Biogeochemistry 39:15-35

Submitted: April 19, 2007; Accepted: July 1, 2008

Proofs received from author(s): October 22, 2008 